DOI: http://dx.doi.org/10.22483/2177-5796.2017v19n1p127-143

\title{
Contribuições do curso de Pedagogia para o letramento acadêmico de seus estudantes
}

\author{
Débora Duarte Monney \\ Rosana Mara Koerner
}

Resumo: Este trabalho apresenta alguns resultados de uma pesquisa sobre letramento acadêmico de estudantes de um curso de Pedagogia. Os dados foram gerados a partir de um questionário respondido por 45 estudantes e entrevista semiestruturada realizada com 8 desses sujeitos. Neste artigo, serão apresentados dados de 4 questões que tinham como foco as influências de leitura e escrita no ambiente acadêmico desses sujeitos. Os resultados mostram que existem influências por parte dos professores do curso pesquisado, principalmente nas questões que envolvem a indicação de leituras de livros, artigos e materiais relacionados ao curso e nas solicitações de escrita de artigos e trabalhos acadêmicos.

Palavras-chave: Formação de professores. Letramento acadêmico. Pedagogia. Influências de leitura e escrita.

\section{Contributions of the course pedagogy for the academic literacy of its students}

Abstract: This paper presents some results of a survey on academic literacy with students from a Pedagogy program. The data were generated from a questionnaire answered by 45 students and from semi-structured interviews conducted with 8 of these subjects. In this article, there will be presented the data from four questions which focused on the reading and writing influences in the academic environment of these subjects. The results show that there are influences by the faculty members of the surveyed program, especially on issues involving the suggestion of readings of books, articles and materials related to the program and the requests for articles and academic papers.

Keywords: Teacher education. Academic literacy. Pedagogy. Reading and writing influences. 


\section{Introdução}

As discussões em torno do letramento acadêmico têm-se intensificado nos últimos anos, considerando-se a clara percepção de que o estudante que chega à universidade hoje tem relações distintas com a escrita daquelas apresentadas há 20 anos ou mais. Seu envolvimento com a escrita é outro, muito permeado pelo digital, pela fluidez e pelo imediatismo característico dos gêneros interativos disponíveis nas redes sociais. Nesse contexto, o estudante de Pedagogia, como aquele que irá contribuir para a inserção de sujeitos no universo da escrita, merece especial atenção no que se refere ao seu próprio envolvimento com a escrita. Como pesquisas têm demonstrado (GATTI, 2014), o público que se dirige a cursos de Pedagogia, em geral, é oriundo de camadas sociais com menor contato com a escrita. Nesse sentido, uma pesquisa que procure reconhecer aspectos relativos ao letramento de estudantes de Pedagogia encontra justificativa para sua realização, até porque ainda são escassos estudos que relacionem letramento com o espaço universitário e, em especial, da formação docente.

Assim, propôs-se uma pesquisa cujo objetivo foi o de identificar as contribuições que o curso de Pedagogia está trazendo para o letramento de seus estudantes. Como procedimentos metodológicos têm-se a aplicação de um questionário a ingressantes e concluintes de um curso de Pedagogia de uma universidade comunitária de Santa Catarina. Para esse texto, serão trazidos os resultados das questões que tematizam as leituras relacionadas ao curso, as dificuldades encontradas nessas leituras, o que esses estudantes escrevem no ambiente acadêmico e as suas percepções quanto às influências de leitura e escrita na sua futura prática docente.

\section{Algumas reflexões iniciais}

Compreender a formação docente significa compreender que o professor é um profissional em processo permanente de formação, não somente a inicial, mas uma formação contínua na busca constante de conhecimentos que darão suporte à sua prática pedagógica. Ser educador é estar constantemente aprendendo por meio de ferramentas e estratégias de aprendizado, sendo que os conhecimentos construídos resultarão em novos conhecimentos, novas construções, novos saberes, em ressignificações do fazer pedagógico. Dessa forma, a profissão docente renova-se todos os dias. Masetto (1994, p. 96) aponta para algumas características da formação do professor:

Quaestio, Sorocaba, SP, v. 19, n. 1, p. 127-143, abr. 2017. 
[...] inquietação, curiosidade e pesquisa. O conhecimento não está acabado; exploração de "seu" saber provindo da experiência através da pesquisa e reflexão sobre a mesma; domínio de área específica e percepção do lugar desse conhecimento específico num ambiente mais geral; superação da fragmentação do conhecimento em direção ao holismo, ao inter-relacionamento dos saberes, à interdisciplinaridade; identificação, exploração e respeito aos novos espaços de conhecimento (telemática); domínio, valorização e uso dos novos recursos de acesso ao conhecimento (informática); abertura para uma formação continuada.

$\mathrm{Na}$ formação "[...] pretende-se obter um profissional que deve ser, ao mesmo tempo, agente de mudança, individual ou coletivamente, e embora seja importante saber o que deve fazer e como, também é importante saber por que deve fazê-lo" (IMBERNÓN, 2010, p. 40). Ainda nas palavras de Imbernón, outro fator importante na formação docente é a atitude que o futuro professor deverá ter ao planejar suas aulas, sendo não apenas um técnico transmissor de conhecimentos, mas um facilitador de aprendizagem, reflexivo, capaz de provocar a cooperação e a participação dos seus alunos.

O professor precisa perceber a sua formação como necessária para a qualificação constante da sua competência profissional e pessoal. Conforme Imbernón (2010), ao assumir esse compromisso, o professor buscará constantemente uma transformação do que está no currículo em aprendizagem significativa para os alunos. Pois, segundo Freire (1996), é pensando criticamente a prática de hoje ou de ontem, que se poderá melhorar a próxima prática. Ou seja, é a partir da análise e interpretação da sua própria prática que o docente tem a possibilidade de tornar-se um profissional reflexivo, crítico e autônomo, contribuindo com a aprendizagem dos seus alunos. Assim, a formação docente não é um ato isolado, e não é uma ação com um fim em si mesma; é um processo contínuo de desenvolvimento profissional que inicia normalmente nos cursos de licenciatura.

A essência dos cursos de Licenciatura é a formação, ou seja, contribuir para o processo de humanização dos alunos, desenvolvendo neles conhecimentos e habilidades, atitudes e valores que contribuam para seus saberes-docentes a partir das necessidades e desafios que lhes serão impostos em suas práticas docentes.

“A carreira docente não tem sido alvo quando os jovens concluintes do ensino médio optam por um curso superior e uma carreira profissional”, conforme Gatti (2014, p. 32). Segundo a autora, o número de matriculados nesses cursos vem caindo ao longo dos anos e o abandono no decorrer do curso é muito alto, estima-se em torno de $70 \%$. Entre os estudantes que procuram os cursos de licenciatura, há características diferenciadas entre esse contingente e que essas 
precisam ser consideradas pelas Instituições de Ensino Superior - IES se pretendem promover a inclusão de todos com qualidade formativa. Conforme a autora, não é possível atuar nas IES como se todos os alunos obtivessem o melhor desempenho no Exame Nacional do Ensino Médio (Enem), na Prova Brasil ou em outros processos avaliativos, e que não apresentem restrições econômicas e diversidades culturais:

Um bom trabalho formativo parte das condições reais dos educandos para atingir ao final um patamar desejável de formação para que possam atuar na educação básica com compromisso e respaldados em conhecimentos disciplinares e pedagógicos consistentes (GATTI, 2014, p. 48).

O curso em questão aqui analisado apresenta em sua matriz curricular disciplinas como: Intertextualidades Literárias, Tecnologia e Mediação Pedagógica, Diversidade e Educação Inclusiva, Práticas de Leitura e Escrita, e Alfabetização e Letramento. Percebe-se então que o curso busca proporcionar aos acadêmicos conhecimentos diversificados, possibilitando assim que este profissional tenha conhecimento e capacidade de atuar profissionalmente em diversas atividades, situações e ambientes. E mais especificamente percebemos que há a inserção desse acadêmico nas discussões sobre práticas de leitura e escrita e letramento, o que ser refletiu em algumas respostas que compõem os dados desta pesquisa. Compreendemos tal situação como parte inequívoca do letramento acadêmico do pedagogo formado neste curso.

Tornar-se letrado hoje envolve muito mais do que o domínio das habilidades básicas da leitura e escrita, visto que muitas são as linguagens que estão disponíveis atualmente. Enquanto as definições tradicionais de letramento tinham o foco na leitura e na escrita, atualmente essa definição é mais complexa. Isso porque, com as mudanças cada vez mais aceleradas do mundo contemporâneo, ser letrado não é um estado que se alcança, mas um processo ininterrupto, em que se busca adquirir novas aprendizagens. Essas ideias de novos letramentos e multiletramentos aparecem com uma perspectiva de que a escola esteja aberta ao ensino das múltiplas linguagens produzidas na atualidade.

Estudar o letramento em si, sem considerar o contexto e as características dos indivíduos e dos grupos onde estão inseridos, não tem fundamento quando se busca conhecer o envolvimento dos sujeitos com a escrita.

Em face ao letramento como o exercício das práticas sociais de leitura e escrita que perpassam em uma sociedade, exigem-se novas demandas para a formação de professores. Dessa 
forma, é necessário que o professor seja também um letrado, especialmente em sua área de conhecimento.

$\mathrm{Na}$ tentativa de identificar as contribuições que o letramento acadêmico traz a estudantes do curso de Pedagogia é preciso considerar que há modelos, formas, locais, agências e agentes de letramento, inseridos em um dado ambiente social, cultural, político e econômico. De acordo com Street (1984 apud SOARES, 2009, p. 75), letramento é "um termo-síntese para resumir as práticas sociais e concepções de leitura e escrita" e que "depende fundamentalmente das instituições sociais que propõem e exigem essas práticas” p. 75).

A escola, como uma importante instituição social, caracteriza-se como uma das principais agências de letramento, na qual se destaca a figura do professor, agente de letramento por excelência. De acordo com Kleiman (2005, p. 82): “[...] uma das possíveis representações do professor, responsável pela inserção dos alunos nas práticas de letramento em contexto escolar, é a de agente de letramento." Ou seja, o professor é visto como aquele que mobiliza os saberes existentes, os recursos e as capacidades dos estudantes buscando o envolvimento em atividades atreladas ao uso da escrita, estimulando assim o letramento de seus estudantes.

Dentro dessa perspectiva, o papel de "formador" do hábito da leitura em seus alunos é uma das atividades do agente de letramento. Para Andrade (2007, p. 11), "Tratando-se de ensino de leitura e escrita, [...], é desejável que o professor tenha tais práticas incorporadas em seu horizonte de experiências cotidianas". Consciente de seu papel de agente de letramento, o professor poderá propor ações mais assertivas na direção do letramento de seus alunos, ou, pelo menos, promover uma reflexão sobre os objetivos pretendidos com o uso de certos materiais em sala de aula.

Nos cursos de formação de professores, é preciso que o estudante entenda a sua transformação na passagem do ser estudante para o ser professor iniciante (GUEDES-PINTO, 2010). Isso pode acontecer a partir da inserção desses professores em formação em práticas de letramento acadêmico durante o curso.

A denominação "letramento acadêmico" pode se referir a contextos que envolvam ambientes e práticas formais de escolarização (Ensino Fundamental, Ensino Médio, Educação de jovens e adultos etc.); no entanto, busca-se aqui ressaltar particularidades da esfera acadêmica no âmbito da graduação. Para Fischer (2008, p. 180), o letramento acadêmico se refere à "fluência em formas particulares de pensar, ser, fazer, ler e escrever, muitas das quais são peculiares a um 
contexto social”. A autora complementa, amparada em Klemp (2004 apud FISCHER, 2007, p. 46), que "letramento acadêmico pode ser definido como um processo de desenvolvimento contínuo de conhecimentos sobre como interagir (modos de compreender e usar) com as diferentes formas e modalidades de textos".

Ao se falar em letramento acadêmico dos estudantes de Pedagogia, não se fala apenas nos conhecimentos necessários para desenvolver textos durante a graduação, mas para o exercício da sua prática pedagógica. No caso dos estudantes de Pedagogia, há que se pensar nas contribuições que esse letramento acadêmico trará a esse profissional responsável por alfabetizar, especialmente para as suas concepções quanto às especificidades dos processos de alfabetização e de letramento como elementos de um grande processo de ensino e aprendizagem.

Ao longo das suas trajetórias acadêmicas, os estudantes experimentam e se apropriam de habilidades e padrões culturais que lhes permitem exercer uma cidadania ativa, reflexiva e participativa em torno do contexto da vida social. Para Lea e Street (1998), são nessas habilidades que consiste o letramento acadêmico. Os autores apontam que as práticas de leitura e escrita realizadas nas esferas acadêmicas, nesse caso no ensino superior, solicitam por parte do sujeito nelas inserido, uma adaptação às novas formas de saber, de interpretação, organização e compreensão do conhecimento.

O letramento acadêmico entende os múltiplos letramentos que estão presentes nas esferas acadêmicas como práticas sociais. De acordo com Oliveira (2010, p. 6): "Essa abordagem atenta para o fato de que as demandas de letramento do currículo universitário envolvem práticas comunicativas que variam de acordo com as disciplinas e os gêneros discursivos em que se inscrevem".

Ser academicamente letrado significa que um estudante possa ter um repertório de estratégias efetivas nas quais consiga compreender e usar diferentes demandas ou práticas textuais (BARTON, 2001 apud FISCHER, 2007, p. 46). Essas funcionam como um elemento das práticas sociais, que indicam a criação e o uso dos textos, e proporcionam mais oportunidades de compreensão crítica do mundo e da palavra (FISCHER, 2007).

Entende-se o letramento acadêmico, na visão de Bunzen (2010), como a junção de aprendizagens adquiridas em torno das esferas acadêmicas, aprendizagens essas que tornam o receptor, ou seja, o estudante, sujeito mais ativo e atuante no contexto acadêmico em que está situado. 
Considera-se também que o cotidiano oferece diversas possibilidades para que os sujeitos exerçam suas práticas de leitura e escrita. Vale destacar que os sujeitos que se dirigem às esferas de letramento acadêmico têm consigo algum nível de letramento, alguma história ou experiência no que diz respeito às práticas sociais de leitura e escrita, trajetórias que poderão contribuir no seu desempenho acadêmico, nos usos que precisará fazer da escrita nessa esfera e, talvez, na prática quando estiver atuando como profissional.

\section{Procedimentos de coleta de dados}

Este texto é um recorte da dissertação de mestrado intitulada "Trajetórias de letramento de estudantes de Pedagogia" e tem por base a pesquisa de cunho qualitativo que, conforme Minayo (1994, p. 21-22), a pesquisa qualitativa,

Trabalha com um universo de significados, motivos, aspirações, crenças, valores ou atitudes, o que corresponde a um espaço mais profundo das relações, dos processos e dos fenômenos que não podem ser reduzidos à operacionalização de variáveis.

Ao escolhermos trabalhar com uma pesquisa com enfoque qualitativo, não excluímos alguns aspectos da abordagem metodológica quantitativa, principalmente quando tratamos do questionário aplicado aos estudantes que depois serviram de sujeitos às entrevistas.

Para esse texto foram selecionadas 4 questões (de um questionário composto de 21 questões), abertas, que contemplavam práticas de leitura e escrita no ambiente acadêmico, as percepções que esses estudantes têm quanto às influências de leitura e escrita na sua futura prática docente. Os números apresentados se referem a essas 4 questões abertas, que foram analisadas e contabilizadas através de recorrências apresentadas pelos estudantes. Também foram realizadas entrevistas com 4 estudantes ingressantes e 4 concluintes (identificados como: ingressantes I1, I2, I3 e I4; e os concluintes como: C1, C2, C3 e C4), cujas respostas serviram para preencher lacunas deixadas pelo questionário. A amostra obtida é composta por 25 estudantes ingressantes e 20 concluintes.

Os estudantes participantes da pesquisa têm, em sua maioria, idade entre 17 e 24 anos. Dentre os motivos da escolha pelo curso de Pedagogia, o principal foi por gostarem de trabalhar com crianças, seguido de terem afinidade com a profissão, incentivo de familiares e a busca pelo conhecimento na área da educação. Além disso, podemos constatar que $80 \%$ dos estudantes 
exercem algum tipo de trabalho, sendo que há uma representatividade grande entre os que trabalham em ambiente escolar. Entre os concluintes, $81 \%$ exercem atividades relacionadas à educação (31\% como professores e 50\% têm uma função em um ambiente escolar). Entre os ingressantes $10 \%$ exercem atividades como professores e 52\% exercem alguma atividade relacionada à educação.

\section{Sobre as práticas de leitura e escrita dos estudantes no ambiente acadêmico}

Inicialmente os estudantes foram questionados sobre as leituras que fazem relacionadas ao curso de Pedagogia. A maioria dos estudantes ingressantes (52\%) e 38\% dos concluintes responderam como primeira alternativa que leem artigos acadêmicos relacionados à pedagogia e à educação. A segunda maior recorrência são livros relacionados à pedagogia: 24\% dos ingressantes e $32 \%$ dos concluintes. E na sequência, entre os ingressantes, $13 \%$ leem Paulo Freire e os concluintes afirmaram que leem textos que tratam do desenvolvimento das crianças, letramento, brincadeiras lúdicas etc., apresentando $22 \%$ das ocorrências. Com essas respostas pode-se perceber que os estudantes priorizam as leituras relacionadas ao curso, muitas delas provavelmente indicadas pelos professores. Os ingressantes, ao citarem Paulo Freire, parecem querer indicar que sabem algo de educação, ou, pelo menos, de um dos autores consagrados na área. Já os concluintes apresentam temáticas que já estão mais relacionadas ao fazer pedagógico, considerando a questão do estágio e da prática docente, pois muitos já atuam como professores.

Percebem-se tais influências conforme algumas falas, como no caso de C4 que disse: “lemos bastante artigos e agora com o TCC né, então leio mais relacionado ao meu projeto e para preparar as aulas do estágio. A gente sempre teve que ler muitos artigos, livros que os professores pedem, [...] leio mais o que eles pedem, por minha conta não”. Percebe-se nessa fala que a estudante está cumprindo o protocolo de estudante, não avançando muito no sentido de ampliar suas práticas de leitura. Já I2 relata que as leituras que os professores solicitam na graduação,

Têm trazido muitos aprendizados né, porque essa semana eu levei um texto para meus alunos e tinha uma citação de Nelly Novaes Coelho que eu trabalhei no início do ano com a professora de intertextualidades, então achei bem interessante, como eu já tinha gostado do texto, já tinha estudado, então eu passei para os meus alunos e disse: oh essa autora já estudei na faculdade, foi bem legal. 
E para a concluinte $\mathrm{C} 3$, "Os livros de literatura e romances eram o que eu mais gostava de ler. Na faculdade os professores pedem a leitura de alguns livros, também. Mas eu sempre estou lendo um livro, não sou de devorar um atrás do outro, mas sempre tem um livro que estou lendo”. Diferentemente do que ocorre com C4, que apenas lê o que lhe é indicado na graduação, C3 expande suas práticas de leitura, busca tempo para ler materiais diversos. Chama a atenção o verbo por ela empregado ao se referir a essa leitura descolada do que se pede na faculdade "devorar", o que parece sugerir o tempo como um empecilho para uma leitura mais intensa.

Conforme relato dos estudantes, há influências por parte dos professores ao pedirem a leitura de livros e artigos. Kleiman (1995) defende que o professor, sendo o principal agente de letramento que está intrinsecamente envolvido com o estudante, deve ter conhecimentos necessários para agir como um agente social, gestor de saber - um agente de letramento -, descobrindo qual o valor da leitura e da escrita na vida do estudante. Assim, poderá possibilitar, através de diversas atividades, a inserção dos estudantes e do seu grupo social no mundo da escrita.

No caso da estudante I1, as influências de leitura na graduação "[...] têm trazido muito conhecimento, até mesmo no modo de falar né. A leitura ajuda a conhecer novas palavras e falar de uma forma mais formal, mais poética, [...] nos dá o contato com outro mundo [...] tanto na literatura infantil, como na... adultos né [...]". Nesse trecho, é possível perceber que a estudante não faz ainda a diferenciação entre linguagem poética e linguagem acadêmica, talvez por estar na condição de ingressante. E a estudante $\mathrm{C} 3$ nos disse: "ah a faculdade me abriu um horizonte assim de temas de leitura, porque antes assim eu lia mais romances, mais de aventura, aqui não, eu comecei a ir mais para o lado da reflexão, do aprendizado, assim mesmo né, da área de pedagogia, da área do conhecimento, do filosófico".

Quando questionados se encontram dificuldades nas leituras realizadas na graduação, $64 \%$ dos ingressantes responderam que sim, $28 \%$ que não e $8 \%$ às vezes encontram dificuldades. Entre os concluintes essas porcentagens se invertem, sendo $50 \%$ os que não têm dificuldades nas leituras, $30 \%$ às vezes e $20 \%$ responderam que encontram dificuldades nas leituras realizadas na graduação. Entre os ingressantes as maiores dificuldades estão nas palavras desconhecidas, seguida de um vocabulário complexo e a falta de compreensão da linguagem presentes nas leituras acadêmicas. Os concluintes apresentam entre as maiores dificuldades a linguagem complexa, seguida da utilização de termos técnicos e uso de uma linguagem formal/norma culta 
padrão. No caso dos ingressantes, são os seus primeiros contatos com as leituras acadêmicas, com uma linguagem até então pouco ou raramente por eles empregada. Quando comparadas as respostas com as dos concluintes, percebe-se que a dificuldade tende a diminuir. Entre os concluintes, a maioria destacou que não encontra dificuldades nas leituras realizadas na graduação, o que indica que houve familiarização da linguagem empregada no campo educacional. Por extensão, pode-se afirmar que seu envolvimento com a escrita acadêmica contribuiu para o seu letramento acadêmico, especialmente a partir do não estranhamento quanto à linguagem que lhe é característica.

Destacamos nessa questão a fala da concluinte $\mathrm{C} 4$, que anteriormente apresentou em seu relato que lê artigos e materiais relacionados ao estágio e TCC, porém, por conta própria não lê, apenas o que os professores ou os trabalhos acadêmicos exigem. Ao questionarmos sobre suas práticas de leitura, a estudante relata que "é bem chato essa leitura mais teórica, eu realmente não consigo ler, já tentei, mas sei lá, é uma linguagem difícil. Tem livros que os professores passam que eu tenho que ler duas, três vezes a mesma página para conseguir entender". Ao identificarmos as dificuldades apresentadas pelos estudantes, nos amparamos em Lea e Street (1998), que apontam que as práticas de leitura e escrita realizadas nas esferas acadêmicas solicitam por parte do sujeito nelas inserido, uma adaptação às novas formas de saber, de interpretação, organização e compreensão do conhecimento. Nesse ponto, parece ser possível indagar acerca das contribuições que o curso está trazendo para o letramento dessa estudante. Por que uma acadêmica que está no último ano da graduação ainda tem dificuldades como essas apresentadas por ela? Quais lacunas ainda restam ser preenchidas no que se refere às habilidades de leitura e escrita ao final do curso? É possível dar conta de todas as lacunas?

É relevante ressaltar que, conforme já apresentado, a metade dos concluintes disse não encontrar dificuldades nas leituras acadêmicas; porém, a outra metade está distribuída em 20\% afirmando ter dificuldade e $30 \%$ ter às vezes. Essas respostas apresentam uma porcentagem significativa e se considerarmos que são estudantes concluintes, ou seja, já cursaram quase quatro anos de graduação, deveriam ter maior facilidade com as leituras acadêmicas. Já foi constatado que os professores solicitam leituras aos estudantes, que há influências de leitura por parte dos docentes; no entanto, por que existem acadêmicos concluintes com dificuldades de leitura? Entre as respostas dos estudantes, as principais dificuldades apresentadas estão na linguagem complexa, na utilização de termos técnicos e no uso de uma linguagem formal/norma culta padrão. Então, se 
a metade dos estudantes disse não ter dificuldades nas leituras acadêmicas, e se há influências de leitura e discussão em sala de aula sobre os temas abordados, estariam então essas dificuldades atribuídas a quê? A questão da linguagem parece ser a principal fonte das dificuldades, seja no nível lexical, seja na estruturação frasal e, ainda, no estilo característico dos gêneros da esfera acadêmica. Tais dificuldades são reconhecidas por parte dos docentes? Há a preocupação com o repertório linguístico desses estudantes, especialmente quando ingressam na universidade. Conforme Fiad (2011), é necessário situar qualquer prática que envolva a leitura e a escrita em um contexto sócio histórico-cultural específico em que o estudante está inserido.

Ao serem questionados sobre a escrita realizada no meio acadêmico, entre ingressantes, os maiores índices apresentados foram trabalhos acadêmicos (36\%) seguido de artigos (23\%) e resumos (10\%). Entre os concluintes as maiores ocorrências foram trabalhos acadêmicos (33\%), seguido de artigos (29\%) e planejamentos (7\%). Embora os resultados tenham ficado muito próximos, entre os concluintes há um gênero diferenciado que são os planejamentos de aulas. Novamente a fase final do curso, com a realização do estágio e a consequente necessidade de preparação de aulas, foi determinante na resposta dada. Além disso, é preciso lembrar, muitos deles já atuam como professores. Com base nesse tipo de produção reafirmamos o que apresenta Bunzen (2010) sobre a junção de aprendizagens adquiridas em torno das esferas acadêmicas, aprendizagens essas que tornam o receptor, ou seja, o estudante, sujeito mais ativo e atuante no contexto acadêmico em que está situado. Essas aprendizagens podem contribuir para o letramento acadêmico, pois “'[...] as demandas de letramento do currículo universitário envolvem práticas comunicativas que variam de acordo com as disciplinas e os gêneros discursivos em que se inscrevem" (OLIVEIRA, 2010, p. 6). E, acrescentamos, podem variar também de acordo com o período de tempo ou fase na qual os estudantes se encontram como foi o caso dos concluintes ao se referirem ao planejamento de aula. Ainda de acordo com Oliveira (2010, p. 6) "[...] uma das características do letramento acadêmico é a exigência de ter de implantar um repertório linguístico adequado às diferentes disciplinas e manipular as identidades e significados sociais que cada uma evoca".

A incidência de trabalhos acadêmicos é reforçada na fala dos entrevistados, quando C3 disse que escreve artigos e trabalhos acadêmicos, principalmente resumos e resenhas que os professores pedem. E a entrevistada $\mathrm{C} 1$ disse: "ah sempre, desde o primeiro ano os professores pediam trabalhos, resumos e eu sempre conseguia transcrever as ideias para o papel. Sempre 
cobraram muito isso da gente e sempre foi bastante significativo, foi positivo para o futuro". A afirmação de $\mathrm{C} 1$ de que tem facilidade em transcrever para o papel as suas ideias, reforçada pelo uso do advérbio "sempre", pode indicar uma avaliação positiva da bagagem que trouxe de sua trajetória prévia ao ingresso na universidade. É preciso relembrar que essa mesma estudante anteriormente apresentou as influências de leitura que teve na infância, em casa, onde tinha inúmeros materiais disponíveis para ler e sempre via o pai lendo. Talvez seja possível indagar acerca de como as influências na trajetória de leitura dessa estudante refletiram na escrita dela como acadêmica posteriormente.

Entre os ingressantes não apareceram recorrentes referências à produção textual solicitada pelos professores, assim como aconteceu com os concluintes, talvez por sua condição de iniciantes. Mesmo não apresentando grandes índices, ocorre, por parte dos professores, a solicitação de trabalhos acadêmicos. O estudante I3 relatou que para ele a questão da escrita acadêmica é difícil: "acho muito difícil pra mim, talvez até por ter vindo do supletivo e porque não tinha o hábito da leitura, eu acho muito complicado desenvolver um texto né, entrar ali na narrativa de um artigo e desenvolver ele". De acordo com Colaço (2012, p. 4): "Ao mesmo tempo em que os gêneros são naturais, eles também exigem conhecimentos específicos de seus usos, o que pode fazer com que uma pessoa que esteja fora de determinada cultura encontre conflitos ao entender ou produzir um gênero". Esse mesmo acadêmico relatou que não teve influências de leitura na sua infância; muito pelo contrário, seus pais o incentivavam a trabalhar e não a estudar. Percebe-se claramente nesses depoimentos que a influência de leitura na infância pode contribuir para o letramento dos sujeitos.

Ao apresentarmos as contribuições/ou não que o curso tem trazido para o letramento dos seus estudantes, buscamos identificar a compreensão de que letramento acadêmico é tudo que contribui para a formação; no caso do pedagogo, incluem-se os gêneros que irão escrever/ler na condição de professores. Entendemos, amparados em Oliveira (2010, p. 6), que o letramento acadêmico é

[...] ter de implantar um repertório linguístico adequado às diferentes disciplinas e manipular as identidades e significados sociais que cada uma evoca. [...] Além disso, esse modelo considera a história de letramento dos alunos e suas identidades sociais, bem como o processo de aculturação pelo qual o estudante passa ao aderir a um novo discurso. 
Por isso, questionamos os estudantes como eles se enxergam na sua futura prática docente quanto às questões de influência de leitura e escrita. Entre as respostas destacamos as de duas concluintes que já atuam no ambiente escolar. C4 diz ser bastante focada na questão da leitura e escrita, conforme seu relato:

Olha, eu sou bastante focada nessa coisa, acho que de tudo o que eu faço na escola é minha parte favorita questão de leitura e escrita, então eu adoro produção textual, eu adoro que as crianças leiam, eu gosto muito que elas escrevam o que elas entenderam do texto, porque hoje em dia elas têm bastante dificuldade em explicar o que elas leram. Então geralmente tu diz assim: o que tu entendeu do texto?, " tudo", tá, mas tudo o quê?. Então eles têm bastante dificuldade. Eu acho que uma coisa que eu vou trabalhar bastante com as minhas crianças é ler bastante, de escrever o que você entendeu, de criar o seu próprio texto [...] eu acho que é bem importante trabalhar essa questão de leitura e escrita, sempre junto uma coisa com a outra, não tem como separar definitivamente e eu acho que, assim, a questão de leitura e escrita vai te ajudar em todas as outras disciplinas, porque interpretação de texto você vai usar em matemática, ciências, vai usar em geografia, então eu acho fundamental [...].

\section{Já C3 disse que}

[...] é o primordial tanto que eu tenho um livro que todo dia 15 minutos eu leio um capítulo para os alunos, então fica assim uma expectativa pra saber o que acontece no próximo capítulo, então eles também gostam muito disso de ouvir, acho muito importante eles poderem ouvir essa leitura do professor e também a questão da biblioteca né, toda a semana eles têm um livro pra ler, eles me contam o que eles [...] falam né, eles também têm o registro das leituras né, que eles escrevem do livro, eles escrevem se gostaram ou se não gostaram e tem a produção semanal né [...].

Percebe-se na fala dessas duas acadêmicas que elas influenciam seus alunos à leitura e à escrita. Na visão delas a leitura é primordial e para C4 é fator principal para bom desempenho nas outras disciplinas, principalmente para a interpretação de textos. Nota-se a partir dos relatos apresentados anteriormente, que há o emprego de estratégias de leitura que promovem o incentivo nas crianças. Onde ou como tais estratégias foram adquiridas? É preciso ressaltar que algumas disciplinas do curso (Intertextualidades Literárias, Leitura e Escrita, Linguística Aplicada à Língua Materna) voltam-se para o ensino da leitura, o que pode, talvez, ter contribuído para uma postura metodologicamente fundamentada de C3 e C4.

\section{I3 destaca que,}

Bem, agora, no início da graduação acho que vai ser difícil até passar para eles porque eu tenho um pouco de dificuldade ainda, mas até o final dos quatro anos acho que eu vou ter superado, eu chamo de um limite, eu acho que eu vou estar bem apto para passar bem a informação para as crianças. Até porque também é um processo de aprendizagem meu, um interesse meu, então eu tendo um bom discernimento, eu acho que vou alcançar esse objetivo sim.

Foi possível perceber na fala desse estudante que ele reconhece a sua própria dificuldade, e aponta que o motivo ainda pode ser pelo fato de estar no início da graduação. Ele afirma 
também que, para estar apto para poder influenciar seus alunos, deverá passar por um processo de aprendizagens e de interesse dele próprio. Dessa forma, o acadêmico reconhece suas limitações e que ele deverá fazer a sua parte buscando conhecimentos e aprendizagens. Ou seja, não basta apenas esperar que o seu professor lhe ofereça caminhos e materiais para esse seu próprio processo de letramento, mas deve partir dele também a busca por outros conhecimentos. Essa percepção pode ser sinal de uma reflexão que o curso está provocando neste estudante?

Analisando as afirmações dos estudantes, nota-se que há influências por parte dos professores na graduação, que cumprem seu papel de agentes de letramento, conceito proposto por Kleiman (2005). A autora afirma que o professor é o responsável por inserir os alunos nas práticas de letramento no contexto escolar. Para que isso ocorra se requer do professor uma postura de agente de letramento, sendo aquele que busca sintonia entre os saberes do aluno e da comunidade ou o meio em que está inserido, para depois planejar e desenvolver suas propostas pedagógicas de leitura e escrita de forma que atenda às necessidades de aprendizagem de cada estudante. E tais considerações também devem ser estendidas à esfera acadêmica, especialmente porque ainda há tão poucos que chegam à universidade no Brasil e tão poucos que dela conseguem sair. O estranhamento inicial do estudante, gerado especialmente pela linguagem empregada nos textos acadêmicos, deve dar lugar a uma gradativa familiarização a partir do trabalho consciente do professor com os gêneros típicos desse ambiente.

Ao analisarmos as contribuições para o letramento desses estudantes, foi possível perceber que há influências de práticas e leitura e escrita por parte dos professores, no entanto, principalmente entre os ingressantes, ainda existem lacunas a serem preenchidas. Entre os concluintes percebeu-se que as influências são maiores, principalmente, entre os estudantes que já atuam como professores, pois em suas falas foi possível perceber que reflexões críticas e consistentes acerca de atividades de promoção do letramento de seus próprios estudantes.

\section{Considerações finais}

Identificar as influências de leitura e escrita de sujeitos em formação inicial, neste caso especificamente caracterizando-se como letramento acadêmico, apresenta-se como necessária para que seja possível perceber os caminhos percorridos por esses estudantes nas questões que o envolvem nas práticas de leitura e escrita. 
$\mathrm{Na}$ análise das quatro questões apresentadas foi possível perceber que entre as leituras relacionadas ao curso, a maioria dos estudantes lê artigos, seguido de livros e textos referentes às disciplinas e à área pedagógica. Entre as leituras realizadas no ambiente acadêmico foi possível perceber que as maiores dificuldades estão entre os ingressantes do que entre os concluintes. Supõe-se que no caso dos ingressantes, as dificuldades apresentadas podem surgir pelo fato de serem seus primeiros contatos com as leituras acadêmicas, com uma linguagem até então pouco ou raramente utilizada por esses estudantes. Entre os concluintes a maioria destacou que não encontra dificuldades nas leituras realizadas na graduação, porém alguns estudantes destacaram que mesmo estando no final do curso ainda têm dificuldades de leitura. Com essas respostas foi possível perceber que houve letramento acadêmico no que tange às influências de leitura, ampliação de vocabulário e à linguagem da área educacional; no entanto, ainda há algumas lacunas a serem preenchidas e dificuldades a serem superadas.

E quanto à escrita realizada na graduação, foi possível perceber tanto entre os ingressantes quanto nos concluintes, que há influências por parte dos professores quanto à produção textual, quando houve destaque à solicitação de trabalhos acadêmicos, artigos e resenhas. Entre os concluintes também apareceu o gênero planejamentos, uma vez que se encontram na fase final do curso, em período de estágio e, também, por alguns já estarem atuando como professores. Contudo, não houve nenhuma manifestação no que se refere à avaliação da habilidade escrita do estudante.

Mesmo percebendo que há influências de leitura e escrita no ambiente acadêmico, existem algumas dificuldades apresentadas pelos estudantes, nas questões de leitura, como palavras desconhecidas, vocabulário complexo e a falta de compreensão da linguagem presentes nas leituras acadêmicas. Nas produções textuais não questionamos específicamente as dificuldades, no entanto, foi possível perceber na fala de uma ingressante que escrita acadêmica é difícil. Face a isso, destacamos que o envolvimento em práticas de leitura e escrita desses estudantes, que futuramente serão professores e formadores, está ocorrendo no ambiente acadêmico, embora de forma muito protocolar, ou seja, limitado ao que é esperado para a produção escrita em ambiente acadêmico. Foi possível perceber que há influências relativas às concepções de leitura na prática pedagógica de alguns dos estudantes que já atuam como professores, como agentes de letramento de seus estudantes, portanto. 
Pelo que foi apresentado, existe a influência de leitura e escrita por parte dos professores, no entanto, ainda há um longo caminho para ser percorrido quando se pensa no professor na interface entre sujeito e profissional, especialmente em suas práticas de leitura. Parece relevante não perder de vista justamente esse aspecto: uma singularidade que se faz a partir de diferentes frentes. E como tal, com dificuldades, com lacunas, com preferências, com ecos de vozes da formação, com propostas pedagógicas - tudo se mesclando em seu fazer diário na sala de aula, com outros sujeitos, também singulares, proporcionando conhecimentos, trocas, experiências e principalmente aprendizados.

\section{Referências}

ANDRADE, Ludmila Thomé de. Professores leitores e sua formação: transformações discursivas de conhecimentos e saberes. Belo Horizonte: Ceale/Autêntica, 2007.

BUNZEN, Clecio. Os significados do letramento escolar como uma prática sociocultural. In: VÓVIO, Claudia Lemos, et al. (Org.). Letramentos: rupturas, deslocamentos e repercussões de pesquisas em linguística aplicada. Campinas: Mercado de Letras, 2010. p. 99-120.

COLAÇO, Silvania Faccin. Práticas pedagógicas de letramento: uma visão ideológica. In: ANPED SUL, 9., 2012, Caxias do Sul - RS. Anais... Caxias do Sul - RS: ANPED, 2012. p. 1-12. Disponível em: <http://www.ucs.br/etc/conferencias/index.php/anpedsul/9anpedsul/paper/view/2148/589>. Acesso em: 16 abr. 2015.

FIAD, Raquel Salek. A escrita na universidade. Revista da ABRALIN, Paraná, v. eletrônico, n. especial, p. 357-369, $2^{\mathrm{a}}$ parte, 2011.

FREIRE, Paulo. Pedagogia da autonomia: saberes necessários à prática educativa. São Paulo: Paz e Terra, 1996.

FISCHER, Adriana. A construção de letramentos na esfera acadêmica. 2007. 340 f. Tese (Doutorado em Linguística) - Programa de Pós-Graduação em Linguística, Centro de Comunicação e Expressão, Universidade Federal de Santa Catarina, Florianópolis, 2007.

FISCHER, Adriana. Letramento acadêmico: uma perspectiva portuguesa. Acta Scientiarum: Language and Culture, Maringá, v. 30, n. 2, p. 177-187, jul./dez. 2008.

GATTI, Bernadete Angelina. Formação inicial de professores para a educação básica: pesquisas e políticas educacionais. Est. Aval. Educ., São Paulo, v. 25, n. 57, p. 24-54, jan./abr. 2014. Disponível em: <http://www.fcc.org.br/pesquisa/publicacoes/eae/arquivos/1899/1899.pdf>. Acesso em: 16 jul. 2015.

GUEDES-PINTO, A. L. Usos de práticas de escrita na formação inicial de professores: interfaces possíveis com os estudos de letramento. In: SERRANI, Silvana. (Org.). Letramento, discurso e trabalho docente. Vinhedo: Horizonte, 2010. p. 129-142.

IMBERNÓN, Francisco. Formação docente e profissional: formar-se para a mudança e a incerteza. 8. ed. São Paulo: Cortez, 2010. 
KLEIMAN, Angela B. Preciso “ensinar” letramento? Não basta ensinar a ler e escrever? Campinas: Unicamp, 2005. Disponível em: <http://www.iel.unicamp.br/cefiel/alfaleras/biblioteca_professor/arquivos 15710.pdf>. Acesso em: 1 maio 2015.

KLEIMAN, Angela B. Modelos de letramento e as práticas de alfabetização na escola. In: KLEIMAN, Angela B. (Org.). Os significados do letramento. Campinas: Mercado de Letras, 1995.

LEA, M. R.; STREET, B. Student writing in higher education: an academic literacies approach. Studies in Higher Education, London, v. 23, n. 2, p. 157-16, jun. 1998.

MASETTO, Marcos Tarciso. Pós-Graduação e formação de professores para o $3^{\circ}$ Grau. São Paulo: Mimeo, 1994.

MINAYO, Maria Cecília de Souza. Pesquisa social: teoria, método e criatividade. 19. ed. Petrópolis: Vozes, 1994.

OLIVEIRA, Eliane Feitoza. Letramento acadêmico: principais abordagens sobre a escrita dos alunos do ensino superior. In: ENCONTRO MEMORIAL DO INSTITUTO DE CIÊNCIAS HUMANAS E SOCIAIS, 2., 2010, Mariana-MG. Anais... Mariana-MG: ICHS, 2010. Disponível em: <www.ichs.ufop.br/memorial/trab2/1113.pdf>. Acesso em: 14 dez. 2015.

SOARES, Magda. Letramento: um tema em três gêneros. 3. ed. Belo Horizonte: Autêntica, 2009.

Débora Duarte Monney - Universidade da Região de Joinville \begin{tabular}{ll|l|l|} 
UNIVILLE. Joinville & SC & Brasil. Contato:
\end{tabular} deboraletras@yahoo.com.br

Rosana Mara Koerner - Universidade da Região de Joinville UNIVILLE. Joinville | SC | Brasil. Contato: debora.duarte@sociesc.org.br 